NANAEKE

Indonesian Journal of Early Childhood Education

Volume 4, Nomor 1, Juni 2021

\title{
PENCAPAIAN INDIKATOR SEKOLAH RAMAH ANAK PADA PAUD DI KECAMATAN MAJAULENG KABUPATEN WAJO
}

\author{
Rismayani \\ Jurusan Pendidikan Islam Anak Usia Dini \\ Fakultas Tarbiyah dan Keguruan UIN Alauddin Makassar \\ Kampus II Jl. H. M. Yasin Limpo No. 36 Samata-Gowa, Sulawesi Selatan \\ Telepon: (0411) 424835 \\ E-mail: rismayani1908@gmail.com \\ Ahmad Afiif \\ Jurusan Pendidikan Islam Anak Usia Dini \\ Fakultas Tarbiyah dan Keguruan UIN Alauddin Makassar \\ Kampus II J. H. M. Yasin Limpo No. 36 Samata-Gowa, Sulawesi Selatan \\ Telepon: (0411) 424835 \\ E-mail: ahmad.afiif@uin-alauddin.ac.id \\ Besse Marjani Alwi \\ Jurusan Pendidikan Islam Anak Usia Dini \\ Fakultas Tarbiyah dan Keguruan UIN Alauddin Makassar \\ Kampus II JI. H. M. Yasin Limpo No. 36 Samata-Gowa, Sulawesi Selatan \\ Telepon: (0411) 424835 \\ E-mail: marjanialwi@gmail.com \\ Ilyas Ismail \\ Fakultas Tarbiyah dan Keguruan UIN Alauddin Makassar \\ Kampus II J. H. M. Yasin Limpo No. 36 Samata-Gowa, Sulawesi Selatan \\ Telepon: (0411) 424835 \\ E-mail: ilyas.ismail@uin-alauddin.ac.id
}

\begin{abstract}
Abstrak
Penelitian ini bertujuan untuk mendeskripsikan indikator-indikator pencapaian pendidikan ramah anak yang diterapkan lembaga pendidikan anak usia dini di Kecamatan Majauleng Kabupaten Wajo. Tulisan ini dihasilkan melalui penelitian lapangan (Field Reaserch) metode Kualitatif deskriptif. Sumber data berasal dari lingkungan dan bangunan sekolah TK Negeri Pembina dan TK PGRI Totengriajarangi. Teknik pengumpulan data dilakukan dengan cara observasi dan dokumentasi dengan teknik analisis data melalui tiga tahap yaitu tahap reduksi data, data display, dan tahap penarikan kesimpulan verifikasi data. Hasil penelitian menunjukkan bahwa berdasarkan 4 komponen pendidikan ramah anak sekolah TK Negeri Pembina telah menerapkan yaitu: 1) komponen Kebijakan sekolah menerapkan 7 indikator; 2) Pelaksanaan kurikulum menerapkan 7 indikator; 3) Pendidik dan tenaga kependidikan terlatih hak anak dengan 2 indikator tercapai dari 7 indikator; 4) Komponen sarana prasarana memenuhi 13 dari
\end{abstract}


16 indikator. Sekolah TK PGRI Totengriajarangi telah menerapkan 4 komponen yaitu: 1) Komponen kebijakan sekolah menerapkan 2 dari 7 indikator; 2) komponen pelaksanaan kurikulum menerapkan 7 indikator; 3) Pendidik dan tenaga kependidikan terlatih hak anak menerapkan 1 dari 7 indikator; 4) Komponen sarana prasarana menerapkan 13 dari 16 indikator. Implikasi penelitian ini adalah untuk mengembangkan pendidikan yang berkualitas bagi peserta didik serta mewujudkan lingkungan yang mendukung peserta didik untuk menumbuh kembangkan potensi yang ada dalam diri peserta didik.

Kata Kunci: Sekolah Ramah Anak; Lembaga PAUD

\begin{abstract}
This study describes the indicators of child-friendly educational achievement metrics of early childhood education institutions in Majauleng District, Wajo Regency. It was field research that has carried out through a descriptive qualitative approach. The data collected through observation and documentation of the TK Negeri Pembina and TK PGRI Totengriajarangi's surroundings and school buildings. Techniques analysis of the data involved three stages, namely the data reduction, display, and the conclusion of data verification. The results showed that based on four components of childfriendly education, the TK Pembina State had: 1) school policy component that implemented seven indicators, 2) Curriculum implementation that implemented seven indicators, 3) Trained of children's rights among educators and education staff implemented two of seven, and 4) Components infrastructure implemented 13 of 16 indicators. Meanwhile, the TK PGRI Totengrijajargi Kindergarten school had implemented four components, namely: 1) school policy component that applied 2 of 7 indicators, 2) the curriculum implementation applied seven indicators; 3) Trained of children's rights among educators and education staff applied 1 of 7 indicators; 4) The infrastructure component applied 13 of the 16 indicators. It implies that the quality of the school environment would support the quality of student education to reach their full potential.
\end{abstract}

Keywords: Child Friendly School; PAUD Institution

\title{
PENDAHULUAN
}

Pendidikan menurut Ki Hajar Dewantara berarti segala kekuatan kodrat yang ada pada diri anak sebagai anggota masyarakat yang hendak mencapai kemaslahatan dan kebahgiaan setinggi-tingginya. Pendidikan merupakan upaya memanusiakan manusia, upaya untuk menggalih dan menumbuh kembangkan potensi yang ada dalam diri peserta didik, pendidikan dilakukan untuk mencapai suatu kompetensi secara optimal melalui kegiatan belajar (Sholichah, 2018).

Berdasarkan Undang-Undang Republik Indonesia Nomor 20 Tahun 2003 tentang Sistem Pendidikan Nasional, pendidikan adalah usaha sadar dan 
terencana untuk mewujudkan suasana belajar dan proses pembelajaran agar peserta didik secara aktif mengembangkan potensi dirinya untuk memiliki kekuatan spiritual keagamaan, pengenalan diri, kepribadian, kecerdasan, akhlak mulia, serta keterampilan yang diperlukan dirinya, masyarakat, bangsa dan Negara. Islam Omar Mohammad Al-Toumy Al-Shaibani tentang tujuan pendidikan adalah mewujudkan perubahan menuju pada kebaikan (Misnatun, 2017). Tujuan pendidikan dalam Islam menuru Zakiah Daradjat yaitu untuk menciptakan kepribadian bisa menjadi insan kamil yang bertakwa, Insan kamil yang berarti manusia yang jasmani dan rohaninya utuh dapat berkembang dan hidup dengan normal dan bertakwa kepada Allah SWT (Azhari, 2014).

Menurut Ridho (2015) salah satu lembaga pendidikan yang sangat memerhatikan pertumbuhan dan perkembangan peserta didiknya yaitu lembaga PAUD, pihak yang berusaha mengupayakan penyelenggaraan pendidikan yang hanya berfokus pada pengembangan peserta didik seperti pengembangan nilai agama, moral, sosial emosional dan kemandirian serta pengembangan kemampuan dasar yang dilakukan secara terpadu menggunakan pendekatan tematik. Sedangkan menurut Qudsyi (2010) pendidikan anak usia dini (PAUD) adalah salah satu lembaga pendidikan yang memfasilitasi anak dalam mengoptimalkan segala potensi perkembangan yang ada pada mereka agar dapat berkembang sesuai harapan.

Sejalan dengan pendapat Masfiah (2013) mengenai ciri-ciri lembaga pendidikan anak usia dini yaitu sekolah dengan tujuan membantu anak didik untuk mengembangkan segala potensi dalam diri anak didik. Sehingga lembaga pendidikan anak usia dini memang seharusnya menjadi tempat yang menyenangkan, nyaman serta aman bagi para siswa untuk melakukan aktivitas pendidikan, anak peserta didik bebas berkreasi, berekspresi dalam belajar dengan suasana lingkungan pendidikan yang penuh dengan kasih sayang dan ramah anak hal ini diutarakana oleh Syafi'i (2017). Perkembangan pendidikan di lingkungan sekolah kini telah memiliki berbagai ciri khas yang hendak menimbulkan rasa nyaman bagi peserta didik dalam belajar, ciri-ciri tersebut berupa sekolah ramah anak, sekolah terpadu, sekolah internasional, sekolah berkarakter, sekolah alam, sekolah multiple intelegence, dan sebagainya (Utami, 2017). Salah satu ciri khas sekolah yang memberikan dukungan terhadap pendidikan baik lingkungan maupun suasana yang dibutuhkan oleh peserta didik yaitu sekolah yang berbasisi pendidikan ramah anak.

Cross (2011) menyatakan tentang intervensi sekolah ramah anak dirancang menggunakan seluruh bagian disekolah untuk membangun hubungan siswa dengan pihak-pihak lain agar mengurangi kemungkinan terjadinya intimidasi namun memberikan kesempatan kepada setiap siswa menikmati fasilitas sekolah dalam mengembangkan diri secara aktif, kreatif dan efektif. Selain itu sekolah yang ramah anak akan menjadi lingkungan yang didalamnya telah dilengkapi sarana 
prasarana yang sesuai dengan kebutuhan dan karakteristik anak, juga sebagai konsep multidimensional yang kondusif bagi anak untuk belajar, khususnya anak usia dini (Diyanti, 2014).

Menurut Arifin (2019) pendidikan ramah anak merupakan satu model Berdasarkan Peraturan Menteri Negara Pemberdayaan Perempuan dan Perlindungan Anak, sekolah ramah anak adalah lembaga pendidikan formal, non formal, dan informal yang dirancang untuk memberikan rasa aman, bersih, dan sehat, peduli lingkungan dan berbudaya, mampu menjamin, memenuhi, menghormati hak-hak anak dan melindungi mereka dari kekerasan, diskriminasi, dan penganiayaan lainnya, juga mendukung partisipasi anak-anak terutama dalam perencanaan kebijakan, pembelajaran, pengawasan, dan mekanisme pengaduan terkait dengan pemenuhan hak dan perlindungan anak-anak dalam pendidikan.

Pendekatan pendidikan yang mengutamakan nilai humanistik atau cara mendidik dalam proses pembelajaran. Sedangkan Arismantoro menyatakan bahwa pendidikan ramah anak lebih kepada upaya menciptakan lingkungan belajar yang kondusif (condusive learning community) sehingga proses pembelajaran yang anak ikut berjalan dengan aktif dan efektif (Yulianto, 2016). Begitu pula Fikriyah (2019) menambahkan bahwa sekolah ramah anak adalah implementasi dari pendidikan ramah anak yang berupa unit, non-formal, pendidikan formal dan informal yang akan menjamin, menghormati, memenuhi hak-hak anak serta menjauhkan anak dari tindak kekerasan dan diskriminasi. Sehingga implementasi sekolah ramah anak kini bertujuan untuk memenuhi hak-hak anak secara keseluruhan dan diharapkan sekolah yang berbasis ramah anak mampu melahirkan gerasi penerus berkepribadian yang ramah, sopan, santun, jujur dan lainnya (Sayekti, dkk, 2018).

Berdasarkan observasi awal secara tidak terstruktur yang dilakukan oleh peneliti di Sekolah TK Arrahman Towalida Kecamatan Sajoanging mengenai lingkungan sekitar sekolah serta sarana prasarana di sekolah tersebut didapatkan gambaran bahwa taman dan ruang kelas sekolah tersebut tidak sesuai dengan indikator-indikator yang ada pada pedoman prasarana pendidikan anak usia dini Kementerian Pendidikan dan Kebudayaan Republik Indonesia tahun 2014. Hal ini dilihat dari segi kebersihan taman, banyak rumput-rumput yang harus dirapikan karena rumputnya sudah mulai memanjang, ruang belajar (kelas) dapat dilihat dari media, alat peraga, buku, pajangan hingga kursi dan meja yang disediakan sekolah untuk peserta didik masih kurang, tidak adanya toilet, kelas yang berada dalam satu gedung yang dibatasi oleh 1-2 lemari.

Berlandaskan latar belakang di atas peneliti tertarik untuk melakukan analisis tentang Pendidikan Ramah Anak di Sekolah Taman Kanak-Kanak Negeri Pembina Desa Rumpia dan Sekolah PGRI Totengria.jarangi Kelurahan Paria Kecamatan Majauleng. Hal ini dilakukan untuk mengetahui bagaimana penerapan pendidikan ramah anak pada jenjang pendidikan anak usia dini. 


\section{METODE PENELITIAN}

Jenis penelitian ini adalah penelitian lapangan (Field Reaserch) metode kualitatif deskriptif (Saat, 2018). Jenis penelitian yang menggunakan dasar alamiah yang bermaksud untuk menafsirkan fenomena yang terjadi dan dilakukan oleh suatu individu atau kelompok. Objek yang menjadi sumber informasi utamana dalama penelitian ada dua yaitu sekolah TK Negeri Pembina di J. H. A. Oddang, Desa Rumpia, Kec. Majauleng, Kab. Wajo dan TK PGRI Totengriajarangi J. Poros Tosora Kelurahan Paria Kec. Majauleng Kab. Wajo, dimana penelitian dilakukan mulai dari tanggal 12 hingga 15 Mei 2020. Adapun pemilihan objek penelitian berdasarkan; (1) Memiliki izin operasional; (2) Sekolah yang mudah di akses peneliti; (3) Kepala sekolah memberi izin untuk melakukan penelitian di sekolah.

Teknik pengumpulan data dilakukan dengan observasi terstruktur jenis observasi Non Participant observation mengadakan pengamatan serta pencatatan secara sistematis tanpa ikut serta didalam kegiatan objek (Djaali, 2007). Sedangkan Instrumen penelitian menggunakan lembar observasi sebagai lembar pengamatan untuk mengukur kesesuaian antara aturan penyelenggaraan pendidikan ramah anak yang berlandaskan panduan sekolah ramah anak dalam peraturan Kementerian Pemberdayaaan Perempuan dan perlindungan Anak dengan apa yang telah diterapkan pendidik di sekolah kemudian dibuktikan dengan dokumentasi. Teknik pengolahan analisis data menggunakan teknik reduksi data, penyajian data dan penarikan kesimpulan dan verifikasi. Selanjutnya pengujian keabsahan data peneliti memerhatikan 2 kategori yaitu Triangulasi teknik dan Triangulasi sumber.

\section{HASIL PENELITIAN}

\section{Indikator Komponen Kebijakan Sekolah Ramah Anak}

Berdasarkan hasil observasi pada 12 Mei 2020 di TK Negeri Pembina Desa Rumpia Kecamatan Majauleng Kabupaten Wajo, sekolah tersebut telah menerapkan 7 indikator komponen kebijakan sekolah dalam pendidkan ramah anak yaitu; 1) Memiliki pedoman dan menerapkan norma, standar, prosedur dan kreteria untuk PAUD; 2) Memiliki kebijakan kekerasan diskriminasi terhadap peserta didik yang berupa poster, peraturan sekolah tertulis; 3) Memiliki kebijakan anti kekerasan tertulis tentang larangan hukuman badan, seperti mencubit, mencambuk, menampar, memukul; 4) Terdapat kebijakan anti kekerasan tertulis yang bersifat menjatuhkan martabat peserta didik, seperti meremehkan, mengejek, dan menyakiti perasaan dan harga menyakiti perasaan dan harga diri peserta didik; 5) Terdapat SOP tertulis untuk tindak lanjut bagi pendidik dan tenaga kependidkan yang melakukan kekerasan terhadap peserta didik maupun sesame pendidik dan tenaga pendidikan; 6) Terdapat aturan mengenai mekanisme pengaduan dan penanganan tertulis kasus kekerasan, termasuk kejahan seksual; 7) Menjamin, melindungi, serta memenuhi hak peserta didik dalam beribadah sesuai dengan 
agama yang dianut.

Beberapa buku pedoman sekolah yang ditemukan seperti pedoman standar prosedur dan kriteria untuk PAUD, pendoman anti kekerasan, panduan perlindungan terhadap kekerasan psikis, panduan perlindungan anak terhadap tindak diskriminasi, panduan terhadap kekerasan fisik pada anak, buku seri bacaan yang disediakan sekolah untuk orang tua dan pendidik tentang KDRT dan pelecehan seksual dalam kehidupan AUD, serta panduan perlindungan anak terhadap anak dilingkungan sekolah lengkap dengan contoh perlakukanperlakukan pelanggaran, peraturan pemerintah tentang tindakan yang tidak baik terhadap peserta didik, serta hukuman bagi para pelanggar hukum, selanjutnya telah memenuhi indikator menjamin dan memenuhi hak peserta didikuntuk menjalankan ibadah dapat dilihat sekolah telah menyiapkan ruang ibadah.

Berdasarkan hasil observasi pada 15 Mei 2020 di sekolah TK PGRI Totengriajarani didapatkan gambaran bahwa sekolah TK PGRI Totengriajarangi telah menerapkan 2 dari 7 indikator yaitu 1) memiliki kebijakan anti kekerasan dan (bullying) terhada peserta didik yang berupa, buku, poster, aturan tertulis lainnya; 2) Memiliki kebijakan anti kekerasan tertulis tentang larangan hukuman badan, seperti mencubit, mencambuk, menampar, memukul; 3) Memiliki kebijakan anti kekerasan tertulis yang bersifat menjatuhkan martabat peserta didik, seperti meremehkan, mengejek, dan menyakiti perasaan harga menyakiti perasaan, harga diri peserta didki; 4) Memiliki SOP tertulis untuk tindak lanjut bagi pendidik dan tenaga kependidkan yang melakukan kekerasan terhadap peserta didik maupun sesame pendidik dan tenaga pendidikan; 5) Adanya mekanisme pengaduan dan penanganan tertulis kasus kekerasan, termasuk kejahan seksual. Hal ini dibuktikan disekitar sekolah tidak ada slogan, tidak ada buku panduan maupun buku penangan tindak kekerasan atau pedoman tentang anti kekerasan dan diskriminasi yang disediakan sekolah sebagai acuan.

\section{Komponen Pelaksanaan Kurikulum}

Berdasarkan hasil observasi di TK Negeri Pembina dapat dilihat sekolah tersebut telah memenuhi 7 indikator pada komponen pelasanaan kurikulum mulai dari tersedianya kurikulum sebagai padoman sekolah, tersedianya rencana pelasanaan pembelajaran mingguan dan harian (RPPM dan RPPH) disetiap kelas, penataan ruang kelas seperti model meja dan kursi di ubah dua kali dalam sebulan, penataan alat-alat permainan dan hasil karya anak di meja karya, hiasan dinding yang berwarna-warni, poster-poster hewan, buah-buahan, lambing bilangan hingga beberapa gambar tata cara sholat, berwudhu, dan doa sehari-hari. Beberapa jenis APE tersusun di dalam lemari seperti balok angka, balok huruf, patung tata cara sholat dan wudhu, pohon angka dan masih banyak lainnya. Namun untuk indikator pelaksanaan kegiatan pembelajaran hanya dapat dilakukan didalam ruangan. 
Sekolah TK PGRI Totengriajarangi berdasarkan hasil observasi juga telah memenuhi indikator-indikator dalam komponen ini, dilihat dari kelengkapan dokumen-dokumen sekolah yang diperlihatkan mulai dari kurikulum sekolah, RPPM dan RPPH setiap kelas, lembar penilaian hingga catatan anekdot. Tersedianya alat permainan edukatif seperti angklung untuk kegiatan seni musik, puzzle bergambar, bangunan tempat beribadah agama ukuran mini, alat dan bahan kegiatan meronce, jam angka, rambu-rambu lalu lintas ukuran mini, serta beberapa gambar profesi berbentuk 3 dimensi ukuran mini terbuat dari papan.

Berdasarkan informasi yang diberikan oleh Ratna Sari salah satu guru disekolah tersebut dapat diketahui bahwa untuk penataan ruang kelas seperti model susunan meja dan kursi hanya dilakukan sebulan sekali, sedangkan untuk pelaksanaan kegiatan diluar sekolah akan dilaksanakan di beberapa tempat seperti di taman, ruang kelas, UKS sesuai dengan tema kegiatan pada RPPM dan $\mathrm{RPPH}$. Tujuan melakukan penataan kursi adalah untuk memberikan suasana baru bagi peserta didik dalam pembelajaran, selain itu agar anak dapat berinteraksi dengan teman-temannya.

\section{Pendidik dan Tenaga Kependidikan Terlatih Hak Anak}

Berdasarkan hasil observasi di sekolah TK Negeri Pembina didapatkan bahwa 2 diantara 4 hanya merupakan lulusan SMA dan S1 bahasa Indonesia namun mengaku telah paham tentang pendidikan anak usia dini karena sering mnegikuti seminar-seminar tentang pendidikan anak usia dini, hal ini dibuktikan adanya beberapa serifikat seminar serta pelatihan tentang hak dan pendidikan anak PAUD dalam dokumen sekolah, selain itu 2 diantara pendidik disekolah tersebut merupakan Iulusan S1 PAUD hal ini dilihat dari dokumen sekolah yang berisi ijazah para pendidik yang mana 2 diantaranya masuk dalam kreteria standar kompetensi bagi para pendidik berdasarkan Peraturan Menteri Pendidikan Nasional Nomor 16 Tahun 2007 yaitu idealnya kualifikasi akademik bagi pendidik minimal diploma 4 atau sarjana (S1) PAUD, karena dalam indikator pendidik dan tenaga kependidikan masih ada guru yang tidak masuk kreteria yang dimaksud peneliti TK Negeri Pembina dianggap tidak memenuhi indikator ini. Sedangkan untuk tenaga kependidikan seperti petugas keamanan, kebersihan serta guru tenaga kependidikan seperti konseling tidak ada disekolah tersebut.

Sedangkan di sekolah TK PGRI Totengriajarangi didapatkan gambaran bahwa kepala sekolah telah beberapa kali ikut kegiatan pelatihan dan seminar mengenai perkembangan anak usia dini dan lingkungan yang ramah bagi anak dalam sekolah PAUD di kota sengkang, sehingga dapat dilihat bahwa kelapa sekolah TK PGRI Totengriajarangi telah terlatih hak anak. Namun masih ada guru di sekolah tersebut diangganp belum paham tentang pendidikan ramah anak serta terlatih hak anak karena kualifikasi akademik pendidik tidak sehubungan dengan pendidikan anak usia dini. Sekolah TK PGRI Totengriajarangi tidak mempekerjakan petugas 
keamanan dan kebersihan juga tidak memiliki guru konseling. Sekolah ini juga tidak pernah mengadakan kegiatan pelatihan maupun semacam seminar tentang hak-hak anak dan pendidikan ramah anak.

\section{Sarana dan Prasarana}

Berdasarkan hasil observasi di sekolah TK Negeri Pembina di dapatkan gambaran bahwa bangunan sekolah terlihat masih kuat dan kokok, sumber air yang digunakan yaitu sumur bor sehingga kualitas airnya bersih, jernih, tidak berwarna maupun berbau. Sekolah TK Negeri Pembina memiliki 2 gedung kelas dimana dalam satu gedung terdapat 2 kelas di dalamnya sehingga masing-masing kelas dibatasi oleh tripleks, untuk indikator kapasitas ruang kelas nyatanya belum tercapai dilihat dari kesesuaian luas kelas dengan jumlah murid seperti luas setiap gedung berukuran $8 \times 4$ meter, luas 32 meter setara dengan $3200 \mathrm{~cm}$. Kelas A1 terdapat 15 orang anak dan A2 terdapat 15 anak digabungkan karena batas kelas A1 dan A2 hanya tripleks sehingga terdapat 2 kelas dalam satu gedung, sehingga luas lahan yang dimiliki setiap anak yaitu $\pm 1 \mathrm{~m}^{2}$. Sedangkan kelas B1 dan B2 masing-masing berisi 21 orang anak sehingga jumlah dalam satu gedung tersebut ada 42 orang anak sehingga jumlah ruang gerak anak hanya $\pm 0,76 \mathrm{~m}^{2}$. Padahal untuk maksimal jumlah lahan yang di miliki setiap anak minimal $3 \mathrm{~m}^{2}$ menurut Kementerian Pendidikan dan Kebudayaan dalam pedoman persyaratan prasarana pada lembaga PAUD Tahun 2014. Indikator ruang kelas di TK Pembina telah dilengkapi dengan loker per-anak, meja dan kursi yang berukuran mini atau telah sesuai dengan ukuran peserta didik.

Beberapa ruang tambahan seperti ruang konsultasi untuk guru dan orangtua siswa, ruang perpustakaan yang berisi buku-buku cerita, ruang UKS yang dilengkapi dengan kotak P3K, serta ruang beribadah juga telah tersedia di sekolah TK Negeri Pembina. Sedangkan untuk toilet sekolah ini belum memisahkan toilet antara murid laki-laki dan perempuan begitu pula dengan prabot yang dibutuhkan peserta didik telah terpenuhi namun prabot tersbut belum sesuia dengan ukuran peserta didik.

Berdasarkan hasil observasi di sekolah TK PGRI Totengriajarangi dapat dilihat bahwa kondisi bangunan sekolah masih kuat dan berdiri kokoh, sumber air yang digunakan yaitu sumur dengan kualitas air jernih, bersih, tidak berwarna maupun berbau. Sekolah ini menyediakan 2 bangunan dibagi menjadi 3 kelas, masingmasing kelas B1 dan B2 berada pada 1 edung yang sama kemudian dibatasi oleh tripleks sebagai pemisah setiap kelas. Kemudian setiap kelas dilengkapi dengan prabot-prabot berukuran mini atau sesuai dengan ukuran peserta didik, seperti kursi, meja, papan tulis, alat permainan yang disediakan sekolah, loker atau lemari tempat menyimpan tas untuk peserta didik. Indikator kapasitas ruang tidak tercapai dilihat dari jumlah peserta didik luas kelas yang tidak sesuai. Area taman bermain sekolah tersebut menyediakan beberapa alat permainan seperti jungkat 
jungkit, ayunan besi, prosotan dan box panjat yang rata-rata dilengkapi pengaman seperti pegangan, prosotan yang tidak terlalu tinggi dan tegak sehingga aman bagi anak.

Sekolah ini telah menyiapkan ruang serabaguna untuk pertemuan bersama dengan orangtua peserta didik, ruang UKS dilengkapi dengan kotak P3K, ruang beribadah, serta ruangan perpustakaan yang terpisah dari gedung-gedung lainnya, selain sekolah juga telah menyiapkan tempat cuci tangan, tempat berwudhu yang berukuran mini. Selanjutnya indikator yang tidak tercapai yaitu tersedianya toilet terpisah antara murid perempuan dan laiki-laki, namun perabot yang digunakan di dalam toilet masih belum sesuai dengan ukuran peserta didik. Komponenkomponen yang berisi beberapa indikator tersebut merupakan daftar indikator sekolah rama anak yang telah di verifikasin yang dikembangkan untuk mengukur capaian sekolah dalam menerapkan sekolah yang ramah anak khususnya pada lingkungan belajar anak yang hendaknya ramah anak.

\section{PEMBAHASAN}

Pendidikan anak usia dini adalah jenjang pendidikan awal yang ditujukan kepada anak sebelum memasuki pendidikan dasar keatas, sehingga diperlukan stimulasi untuk meletakkan dasar sebagai langkah awal untuk menumbuh kembangkan pribadi, prilaku, karakteristik, potensi serta setiap aspek perkembangan anak. Sukarno L. Hasyim (2015) juga menyatakan bahwa PAUD adalah langkah awal yang akan menjadi fondasi dari kepribadian seorang anak. Sebaiknya pendidikan anak usia dini direncanakan dengan memerhatikan kebutuhan-kebutuhan peserta didik sesuai dengan karakteristik dan fungsinya, hal ini dilakukan agar pelaksanaan pendidikan berjalan secara aktif, efektif dan memberikan kebebasan kepada peserta didik untuk mengekspresikan diri.

Sekolah bukan hanya sebagai gedung tempat belajar, sekolah juga hendaknya miliki sistem yang fasilitasnya memadai memberikan rasa aman, nyaman, bersih dan sehat, berfokus pada anak. Sekolah ramah anak merupakan salah satu sekolah yang berupaya menjamin dan memenuhi hak-hak anak dalam setiap aspek kehidupan secara terencana dan bertanggung jawab, prinsip utama non diskriminasi, kepentingan hak hidup serta penghargaan terhadap anak serta memfasilitasi peserta didik agar dapat tumbuh dan berkembang sesuai harapan. Senada dengan Agus Yulianto (2016) sekolah yang berbasis ramah anak berarti upaya pemberian suasana lingkungan belajar yang memberikan kebebasan perkreasi, berekspresi dan mengembangkan diri namun tetap memerhatikan pedoman pelaksanaan pendidikan. Hal ini yang kemudian memberikan gambaran bahwa sekolah harusnya menjadi tempat yang lebih mengutamakan hak-hak anak dan mengoptimalkan setiap aspek perkembangan atau potensi yang ada dalam diri anak dengan cara yang ramah anak. Sebagaimana Pasal 4 Undang-Undang No. 23 Tahun 2002 tentang Perlindungan Anak, menyebutkan bahwa anak mempunyai 
hak untuk dapat hidup tumbuh, berkembang, dan berpartisipasi secara wajar sesuai harkat dan martabat kemanusiaan, serta mendapatkan perlindungan dari kekerasan dan diskriminasi (Permendikbud, 2014). Berdasarkan panduan pelaksanaan pendidikan ramah anak disekolah berikut 4 dari 6 komponen penerapan pada pendidikan anak usia dini:

Komponen pertama yaitu kebijakan sekolah terhadap pendidikan ramah anak dimana diketahui bahwa Sekolah TK Negeri Pembina telah menerapkan beberapa indikator yang mana membahas tentang kebijakan atau aturan-aturan dan mekanisme pengaduan jika terjadi tindakan yang kurang baik dalam proses pendidikan peserta didik hal ini dilihat dari buku panduan-panduan anti kekerasan, KDRT, anti diskriminasi yang mana berisi aturan, bentuk-bentuk pelanggaran, hukuman bagi pelanggar, Pasal yang mendukung, serta penangan jika terjadi tindakan tidak baik. Sedangkan sekolah TK PGRI Totengriajarangi berdasarkan hasil penelitian belum memenuhi indkator dilihat dari tidak adanya aturan yang yang melarang perlakuan tindak kekerasan, kekerasan dan tindakan lainnya serta tidak adanya SOP penanganan jika terjadi pengaduan terhadap tindakan yang salah terhadap peserta didik. Padahal seharusnya kebijakan sekolah dalam penanganan tindak disktriminasi, kekerasan, pelecehan dan tindakan salah lainnya harus ada disetiap lembaga pendidikan khususnya lemabga pendidikan anak usia dini yang mana merupakan jenjang pendidikan bagia anak usia 4 - 6 tahun, selain itu hal itu merupakan salah satu upaya pendidikan ramah anak.

Sebagaimana Peraturan Menteri Negara Pemberdayaan Perempuan dan Anak Republik Indonesia Nomor 8 Tahun 2014 tentang Kebijakan Sekolah Ramah Anak menjelaskan bahwa sekolah ramah anak merupakan sekolah yang mampu menjamin, memenuhi, menghargai hak-hak anak dan perlindungan anak dari kekerasan, diskriminasi, dan perlakuan salah lainnya. Pelaksanaan pendidikan ramah anak bertujuan memenuhi hak anak khususnya pemberian perlindungan dari tindak kekerasan, diskriminasi, dan perlakuan tidak baik, maka setiap sekolah hendaknya memiliki sistem atau suatu kebijakan berupa aturan, pedoman dalam penanganan suatu pengaduan tentang tindakan salah yang dialami anak dalam proses pendidikan.

Komponen selanjutnya adalah pelaksanaan kurikulum. Berdasarkan hasil disekolah TK Negeri pembina yang mana telah menerapkan indikator-indiaktor pelaksanaan kurikulum dilihat dari ketersediaannya kurikulum, RPPM dan RPPH setiap kelas yang mana didalam rencana program pembelajaran mingguan tersebut berisi beberapa kegiatan yang membahas materi menjaga kebersiha diri dan tempat tinggal, tersediannya APE pembelajaran, serta kegiatan pembelajaran yang bertujuan memberikan pengalaman melalui suasana belajar baru kepada peserta didik dengan belajar bersama diluar kelas. Begitupun dengan sekolah TK PGRI Totengrajangi yang telah menerapkan indikator-indikator pelaksanaan kurikulum dilihat dari kesediaan dokumen panduan kurikulum, RPPM dan RPPH, serta 
beberapa APE yang tersedia didalam kelas.

Pelaksanaan pembelajaran adalah suatu proses kegiatan belajar peserta didik sesuai dengan rencana yang telah diterapkan untuk mencapai standar kompetensi (Depdiknas, 2004). Pelaksanaan kegiatan pembelajaran memerlukan pedoman dalam perencanaannya sehingga dibutuhkan kurikulum sebagai kerangka perencanaan kegiatan dalam pendidikan. Begitupun menurut Sanjaya W. (2011) Kurikulum diartikan sebagai suatu dokumne perencanaan yang berisi tentang tujuan yang hendak dicapai, isi materi, dan kegiatan yang harus dilakukan peserta didik, strategi, metode serta evaluasi yang dirancang untuk mengumpulkan informasi dalam implementasi isi dari kurikulum.

Sebagaimana Undang-Undang Nomor 20 Tahun 2003 tentang Perlindungan Anak menjelaskan kurikulum merupakan seperangkat rencana dan pengaturan mengenai tujuan, isi, dan bahan pengajaran serta cara yang digunakan sebagai pedoman penyelenggaraan kegiatan pembelajaran untuk mencapai tujuan pendidikan nasional (UUD RI). Penting bagi setiap sekolah berbasis ramah anak memenuhi indikator-indikator dalam pelaksanaan kurikulum ini karena kegiatan utama pendidikan di sekolah dalam rangka mewujudkan tujuan kegiatan pembelajaran, sehingga seluruh aktifitas di sekolah bermuara pada pencapaian efisiensi dan efektifitas pembelajaran yang terarah dengan adanya kurikulum. Kerangka yang dimaksud adalah ketersediaannya rencana-rencana program pembelajarn yang menjadipanduan setiap pendidik dalam melaksanakan kegiatan pendidikan (Mulyasa, 2006).

Menurut Peraturan Pemerintah Nomor 19 tahun 2015 tentang 8 Standar Nasional Pendidikan dinyatakan bahwa standar proses dalam satuan pendidikan mencakup proses pembelajaran, pelaksanaan proses pembelajaran, penilaian hasil pembelajaran dan pengawasan proses pembelajaran (Gaol, 2019). Hal tersebut yang kemudian menuntut guru untuk merancang kegiatan pembelajaran sebelum memulai kegiatan pembelajaran agar kegiatan berjalan sistematis dan mencapai tujuan yang hendak dicapai, rancangan yang dimaksud adalah rencana pelaksanaan program mingguan dan harian (RPPM dan RPPH) yang memuat tingkat pencapaian, materi, metode pembelajaran, media, dan sumber belajar serta penilaian yang sesuai dengan usia peserta didik. Hal ini pun menunjukkan bahwa pihak sekolah telah berupaya menerapkan lingkungan yang ramah anak dengan memenuhi indikator-indikator pada komponen kurikulum. Indikator yang dimaksud adalah adanya kurikulum sebagai panduan pelaksanaan pendidikan, tersedianya rencana pelaksanaan program pembelajaran (RPPM dan RPPH) disetiap kelas, dan pengintegrasian materi-materi tentang kebersihan lingkungan hidup didalam RPPM dan RPPH.

Komponen pendidik dan tenaga kependidikan yang mencakup pimpinan satuan pendidikan atau kepala sekolah, pendidik atau guru, anggota komite yang telah terlatih hak anak dan pendidikan ramah anak, serta pelatihan tentang hak 
anak dan pendidikan ramah anak di satuan PAUD. Berdasarkan hasil diketahu bahwa sekolah TK Negeri Pembina hanya memenuhi indikator kepala sekolah terlatih hak anak dilihat dari buku borang profil kepala sekolah yang merupakan Iulusan sarjana S1 jurusan pendidikan anak usai dini, indikator pendidik dan tenaga kependidikan telah terpenuhi dilihat dari jumlah guru lulusan sarjana S1 pendidikan anak usia ini lebih banyak. Sedangkan sekolah TK PGRI Totengriajarangi telah memenuhi indikator kepala sekolah dan pendidik terlatih hak anak hal ini dilihat dari daftar profil guru yang aman 2:2 guru terlatih hak.

Sebagaimana Pemerintah mengembangkan dan menetapkan standar mutu guru melalui Undang-Undang Nomor 4 Tahun 2005 tentang guru dan dosen yaitu kualifikasi akademik guru harus memenuhi standar kompetensi guru, lolos sertifikat, sehat jasmani dan rohani, serta kemampuan untuk mewujudkan tujuan pendidikan (Adriani, 2012). Sejalan dengan Peraturan Menteri Pendidikan Nasional Nomor 16 Tahun 2007 yang menetapkan kualifikasi akademik dan standar kompetensi bagi para pendidik dengan tujuan untuk menjaga mutu pendidikan Indonesia, yang mana pada pendidikan anak usia dini (PAUD), idealnya kualifikasi akademik dan standar kompetensi bagi para pendidik yang dipersyaratkan adalah minimum berada pada tingkat diploma empat (D-IV) atau sarjana (S1) dalam bidang pendidikan anak usia dini atau psikologi yang diperoleh dari program studi terakreditasi (Ratnaningsih, 2015).

Sebagaimana yang diketahui bahwa guru atau seorang pendidik merupakan salah satu komponen pendidikan yang dapat meningkatkan mutu pendidikan, bertugas merencanakan dan melaksanakan proses pembelajaran, menilai hasil pembelajaran, melakukan pembimbingan dan pelatihan, serta melakukan penelitian dan pengabdian kepada masyarakat, sehingga penting bagi pendidik dibekali pengetahuan, kemampuan profesional dalam melaksanakan tugas dalam pendidikan agar dapat membuat suatu kegiatan pembelajaran berjalan sesuai rencana dan dapat mencapai tujuan pendidikan yang diinginkan (Idzhar, 2016).

Komponen sarana prasarana dalam pendidikan ramah anak yang mencakup fasilitas-fasilitas yang disedikan sekolah untuk menunjang kebutuhan anak dalam proses pembelajaran yang diadakan oleh pendidik. Berdasarkan hasil diatas sekolah TK Negeri Pembina telah memenuhi 13 indikator dari 15 indikator dalam komponen sarana prasarana ini yang mana 2 indikator yang tidak dicapai yaitu tersedianya toilet terpisah antara perempuan dan laki-laki dan indikator tersedianya praot toilet pada PAUD, TK dan sejajaranya yang mana menggunakan ukuran mini (pintu, timba, dan tempat cuci tangan). Begitu juga dengan sekolah TK PGRI Totengriajarangi telah memenuhi 13 (tiga belas) dan tidak memenuhi indikator yang sama dengan sekolah Negeri Pembina. Pada hal alat yang sesuai dengan kebutuhan peserta didikbaik dari segi ukuran alat, manfaat dan tujuan unuk mengembangkan aspek-aspek perkembangan peserta didik. Alat yang telah memenuhi syarat kemudian disebut dengan APE alat permainan edukatif yaitu alat 
pembantu dalam pelaksanaan proses pembelajaran peserta didik di sekolah.

Berdasarkan peraturan Pemerintah Nomor 19 Tahun 2005 tentang Standar Nasional Pendidikan pasal 42 ayat 2 yang menyatakan bahwa setiap satuan pendidikan wajib memiliki prasarana yang meliputi lahan, ruang kelas, ruang pimpinan satuan pendidikan, ruang pendidik, ruang tata usaha, ruang perpustakaan, ruang laboratorium, ruang bengkel kerja, ruang unit produksi, ruang kantin, instalasi daya dan jasa, tempat berolahraga, tempat beribadah, tempat bermain, tempat berkreasi, dan ruang atau tempat lain yang diperlukan untuk menunjang proses pembelajaran yang teratur dan berkelanjutan (Peraturan Pemerintah Republik Indonesia, 2005). Hal seperti ini pun yang kemudian harusnya diperhatikan oleh pihak sekolah dalam mewujudkan sekolah yang ramah anak, setiap fasilitas, sarana dan prasarana yang ada disekolah dianggap sebagai salah satu penunjang keberhasilan pelaksanaan kegiatan pendidikan peserta didik

\section{KESIMPULAN}

Penerapan komponen-komponen pendidikan ramah anak yang memuat berbagai macam indikator didalamnya berdasarkan panduan penerapan pendidikan ramah anak pada peraturan Menteri Pemberdayaan dan Perlindungan Anak, berdasarkan hasil penelitian didapatkan gambaran bahwa sekolah TK Negeri Pembina Desa Rumpia Kecamatan Majauleng Kabupaten Wajo 4 komponen pendidikan ramah anak yang pertama komponen kebijakan sekolah memenuhi 7 indikator, komponen pelaksanaan kurikulum memenuhi 7 indikator, komponen pendidik dan tenaga kependidikan terlatih hak anak memenuhi 2 dari 7 indikator, komponen sarana prasarana memenuhi 13 dari 16 indikator diserta beberapa bukti-bukti yang peneliti dpsa. Sedangkan penerapan komponen pendidikan ramah anak sekolah TK PGRI Totengriajarangi Kelurahan Paria Kecamatan Majauleng Kabupaten Wajo yang pertama yaitu komponen kebijakan sekolah mencapai 2 dari 7 indikator, komponen pelaksanaan kurikulum memenuhi 7 indikator, komponen pendidik dan tenaga kependidikan terlatih hak anak memenuhi 1 dari 7 indikator, komponen sarana prasarana memenuhi 13 dari 16 indikator.

Berdasarkan capaian indikator pada komponen pendidikan ramah anak yang diterapkan kedua sekolah dapat diketahui bahwa kedua sekolah belum memenuhi kreteria sekolah yang berbasis pendidikan ramah anak karena masih banyak indikator dalam komponen yang tidak terpenuhi, hal ini pun menunjukkan bahwa sekolah terakreditasi tidak menutup kemungkinan telah menerapkan pendidikan yang ramah anak atau telah menjadi sekolah berbasis hak anak. Sedangkan pendidikan anak usia dini adalah jenjang pendidikan yang sangat berpengaruh terhadap peletakan dasar kepribadian seorang anak melekat hingga mereka dewasa. Selain itu, sekolah hendaknya menjadi tempat yang memfasilitasi peserta didik dalam proses pendidikan, lingkungan sekolah yang memberi kenyamanan dan rasa aman bagi peserta didik serta hal-hal yang ada didalamnya berfokus 
untuk pertumbuhan dan perkembangan potensi serta hak-hak yang hendaknya diterima oleh peserta didik. Maka peneliti berharap setiap PAUD dapat menerapkan komponen-komponen pendidikan ramah anak yang sangat mengutamakan hak-hak anak, selain itu mendukung rencana pemerintah terhadap penerapan pendidikan yang ramah anak disetiap jenjang pendidikan.

\section{DAFTAR PUSTAKA}

Adrian. D. E. (2012). Program Peningkatan Mutu Guru Berbasis Kebutuhan. Jurnal Manajemen Pendidikan. 23 (95)

Arifin., M., Sudarmono dan Desiderius Priyo Sudibyo. (2019). The Implimentation of Child-Friendly Schools: Challenges and Obstacles in the Era of Technological and Information Advancement. Jurnal Advances in Social Science, Education and Humanities Research, 317.

Azhari. (2014). Pendidikan Anak Usia Dini dalam Al-Qur'an (Kajian Tafsir Muqoran Q.S Luqman Ayat 12-15)". [UIN Syarif Hidayatullah]. http://repository.uinjkt.ac.id/dspace/handle/123456789/25129.(diakses 16/07/2020)

Depdiknas. (2004). Kurikulum SMK Edisi 2004b. Jakarta: Depdiknas.

Diyanti., Ayu Oktira. Chairil Budiarto dan Triandriani Mustikawati. (2014). Lingkungan Ramah Anak Pada Sekolah Taman Kanak-Kanak. Jurnal Ruas, 12(2).

Djaali., dan Muljono .(2007). Pengukuran Dalam Bidang Penelitian. Jakarta:Grasindo.

Fikriyah dan Widia Nur Jannah. (2019). Child-Friendly Education Program In Elementary School Toward Traditional Game. Jurnal 4th Progressive and Fun Education International Conference (DFEIC 2019), 355.

Gaol., Ramsi Lumban. (2019). Peningkatan Kompetensi Guru dalam Menyusun Rencana Program Pembelajaran Harian (RPPH) Melalui Peran Pengawas Sekolah Di TK Pertiwi Medan. Jurnal Tematik, 9(1).

Hasyim., Sukarno L. (2015). Pendidikan Anak Usia Dini (PAUD) Dalam Perspektif Islam. Lentera: Kajian Keagamaan Dan Teknologi, 1(2).

Idzhar., A. (2016). Peran Guru dalam Meningkatkan Motivasi Belajar Anak. Office, 2(2).

Iskandar., Uray. (2015). Pengertian dan standar sekolah sehat, aman, ramah anak, dan menyenangkan. http://urayiskandar.com/2015/081 
Kemendikbud. (2014). NSPK (Norma, Standar, Prosedur dan Kreteria) Pedoman Prasarana Pendidikan Anak Usia Dini. anggunpaud.kemendikbud.go.id

Masfiah., Dewi. (2013). Penggunaan Media Kartu Kata Bergambar Untuk Meningkatkan Kemampuan Berbicara Pada Anak Kelompok B Tk Kyai Hasyim Surabaya. Jurusan Pendidikan Guru PAUD Fakultas IImu Pendidikan Universitas Negeri Suraba.

Menteri Negara Pemberdayaan Perempuan dan Perlindungan anak. (n.d.). Peraturan Menteri Negara Pemberdayaan Perempuan dan Perlindungan Anak Nomor 8 Tahun 2014 Tentang Kebijakan Sekolah Ramah Anak. https://disdikpora.bulelengkab.go.id

Mahnun., Nunu. (2012). Media Pembelajaran (Kajian Terhadap Langkah-Langkah Pemilihan Media dan Implementasinya dalam Pembelajaran). Pemikiran Islam, 37(1).

Mulyasa., Enco. (2006). Kurikulum Berbasis Kompetensi, Konsep Karakteristik, dan Implementasinya. Bandung: Remaja Rosdakarya.

Permendikbud. (2014). Peraturan Menteri Pendidikan dan Kebudayaan Republik Indonesia No. 137 Tahun 2014 Tentang Standar Nasional Pendidikan Anak Usia Dini. http://repositori.kemdikbud.go.id/12860/. (diakses 18/09/2020)

Qudsyi., Hazhira. (2010). Optimalisasi pendidikan anak usia dini melalui pembelajaran yang berbasis perkembangan otak. Buletin Psikologi, 18(2).

Ratnaningsih., Izriz. UPU Prihatsanti. dan ARPAR Prasetyo. A. R. (2015). Pelatihan bagi kader pendidikan anak usia dini (PAUD) Kecamatan Banyumanik Semarang. Info, 17(2).

Ridho., Rosyid. Markamah dan Darsinah (2015). Pengelolaan Pembelajaran Pendidikan Anak Usia Dini (PAUD) Di KB “Cerdas" Kecamatan Sukorejo Kabupaten Kendal. Penelitian Humaniora, 16(2).

Saat., Sulaiman dan Sitti Mania. (2018). Pengantar Metodologi Penelitian Panduan Bagi Peneliti Pemula.

Sanjaya, W. (2011). Pembinaan dan Pengembangan. Jakarta: Kencana.

Sayekti., Ika. Candra, Novita Wulan Sari, Nabila Alfarina Mutiara Primasti dan Megan Nina Sasarilia. (2018). Muatan Pendidikan Ramah Anak dalam Konsep Sekolah Alam. JPPD, 5(1).

Sholichah., Aas Sitti. (2018). Teori-teori Pendidikan dalam Al-Qur'an. Pendidikan Islam, 7(1).

Syafi'i., A. (2017). Upaya Kepala Sekolah Dalam Mewujudkan Sekolah Ramah Anak

40 NANAEKE - Indonesian Journal of Early Childhood Education, Vol. 4, No. 1, Juni 2021 
Di SDIT Nur Hidayah Surakarta Tahun Pelajaran 2016/2017. Jurusan Pendidikan Agama Islam Fakultas IImu Tarbiyah dan Keguruan Institut Agama Islam Negeri (IAIN) Surakarta.

Utami., Ratnasari Diah. Mulat Kurnianingsih Dwi Saputra dan Farida Nur Kartikasari. (2017). Implementasi Penerapan Sekolah Ramah Anak Pada Penyelenggaraan Pendidikan Sekolah Dasar. The 5th URECOL Proceeding.

Undang-Undang Nomor 14 Tahun 2005 tentang Guru dan Dosen. Http://manlbengkalis.sch.id

Peraturan Pemerintah Republik Indonesia Nomor 19 Tahun 2005 tentang Standar Nasional Pendidikan. Http//:pelayanan.Jakarta.go.id

Undang-Undang Republik Indonesia Nomor 20 Tahun 2003 tentang Sistem Pendidikan Nasiona. http://luk.staff.ugm.ac.id.

Yulianto., A. (2016). Pendidikan Ramah Anak Studi Kasus SDIT Nur Hidayah Surakarta. Kajian Kependidikan Islam, 1(2). 